\title{
Cryopreservation of papaya seeds cv. Sukma, Callina, and Caliso: Effect of loading treatment and immersion time in plant vitrification solution-2
}

\author{
FITRI FATMA WARDANI ${ }^{1, \vartheta}$, DARDA EFENDI ${ }^{2,3, v v}$, DINY DINARTI ${ }^{3}$, JOKO RIDHO WITONO ${ }^{4}$ \\ ${ }^{1}$ Program of Plant Breeding and Biotechnology, Graduate School, Institut Pertanian Bogor. Jl. Raya Dramaga, IPB Darmaga Campus, Bogor 16680, West \\ Java, 16680, Indonesia. ”email: fitrifatmawardani@gmail.com \\ ${ }^{2}$ Center for Tropical Horticulture Studies, Institut Pertanian Bogor. J1. Raya Pajajaran, IPB Baranangsiang Campus, Bogor 16129, West Java, Indonesia \\ Tel.: +62-251-8326881, "^email: dardaefendi@gmail.com \\ ${ }^{3}$ Department of Agronomy and Horticulture, Institut Pertanian Bogor. Jl. Raya Dramaga, IPB Darmaga Campus, Bogor 16680, West Java, 16680, \\ Indonesia \\ ${ }^{4}$ Research Research Centre for Plant Conservation and Botanic Gardens (Bogor Botanic Gardens), Indonesian Institute of Sciences. Jl. Ir. H. Juanda No. \\ 13, Bogor 16122, West Java, Indonesia
}

Manuscript received: 12 February 2019. Revision accepted: 20 March 2019.

\begin{abstract}
Wardani FF, Efendi D, Dinarti D, Witono JR. 2019. Cryopreservation of papaya seeds cv. Sukma, Callina, and Caliso: Effect of loading treatment and immersion time in plant vitrification solution-2. Nusantara Bioscience 11: 71-78. Sukma, Callina, and Caliso are papaya cultivars released by the Center for Tropical Horticulture Studies, IPB University, Bogor, West Java, Indonesia. In general, papaya seeds cannot be stored for a long time with a conventional GenBank storage system, even though some of them consider as "orthodox" class of seed. Cryopreservation, storage at an ultra-low temperature $\left(-196{ }^{\circ} \mathrm{C}\right)$ of liquid nitrogen, could be possible for longterm storage of papaya seeds. The experiment conducted to get the necessary of loading treatment and the best immersion time in PVS2 for cryopreservation of papaya seeds cv. Sukma, Callina, and Caliso, so they still had considerable viability. We conducted experiment as factorial in completely randomized design, with the first factor was loading treatment with two levels (with and without loading treatment), and the second factor was immersion time in PVS2 with three levels (15, 30 and 45 min). So, there was six treatment and we used 50 seeds for each treatment. Results showed that the three papaya cultivars gave different responses to the treatment before cryopreservation proved that papayas seed had different characteristics, depending on genotype. For papaya seeds cv. Sukma, loading treatment was not needed and the best immersion time in PVS2 was $15 \mathrm{~min}$. The viability of papaya seeds cv. Callina was low, so we should try another treatment before cryopreservation. For papaya seeds cv. Caliso, loading treatment was needed and the best immersion time in PVS2 was 30 min.
\end{abstract}

Keywords: GenBank, liquid nitrogen, long-term storage, orthodox seed, ultra-low temperature

Abbreviations: DMSO: dimethyl sulfoxide, LS: loading treatment, PVS2: plant vitrification solution 2, MC: Moisture content, GP: Germination percentage, GR: Germination rate, VI: Vigor index, MGP: Maximum growth potential

\section{INTRODUCTION}

Papaya (Carica papaya L.) is one of tropical fruit native to Southern America and had been cultivated in Indonesia. Papaya fruits contain many nutrients such as carbohydrates, vitamin A, vitamin $\mathrm{C}$, vitamin B-6, minerals $(\mathrm{Na}, \mathrm{Mg}, \mathrm{Cu}, \mathrm{Zn}, \mathrm{Mn}, \mathrm{Ca}, \mathrm{P}, \mathrm{K}, \mathrm{Fe})$, protein, fat, and high in fiber (Silva et al. 2007). Papaya breeding has been carried out by the Center for Tropical Horticulture StudiesBogor Agriculture University (PKHT-IPB) since 2000 and got 13 papaya cultivars (PKHT 2018). Some of the new papaya cultivars were Caliso for small-sized papaya (300$500 \mathrm{~g}$ ), Callina for medium-sized papaya (800-1200 g) and Sukma for large-sized papaya (more than $1200 \mathrm{~g}$ ).

Papaya propagation is often carried out by using seeds so continuous availability and proper seed storage management is needed. The seeds of some papaya cultivars can be orthodox, but their shelf life was relatively short compared to other orthodox seeds from the other plant
(Salomao and Mundin 2000). Therefore, seed storage method is needed that can prolong the storability of papaya seeds.

Cryopreservation is a storing method of plant material in liquid nitrogen $\left(-196{ }^{\circ} \mathrm{C}\right)$ so the metabolism in cells, tissues, and organs become stopped. Therefore, plant material such as seeds can be stored for a long term without experiencing genetic changes or somaclonal variations (Hervani et al. 2016). The new cryopreservation method or vitrification is widely used method because it is easier to implement and the results are good for various species (Wang et al. 2008). For example, embryogenic culture of avocado recovered from cryopreservation through vitrification demonstrate normal growth, and somatic embryos can be recovered (Efendi and Litz 2003). Shoottips of Byrsonima intermedia A. Juss. that stored by cryopreservation with vitrification method, presented satisfactory regrowth level (67\%) (Silva et al. 2013). Protocorm-like bodies (PLBs) of Brassidium Shooting Star 
orchid were successfully cryopreserved using dropletvitrification method (Rahmah et al. 2015).

Vitrification is water transition process from liquid to amorphous or glassy phase to prevent ice crystal formation when freezing in the liquid nitrogen and thawing (warming) (Elliot et al. 2017). The main process in vitrification was done by cryoprotectant. Cryoprotectant is solution that protects cell from freezing and thawing (Vendrame et al. 2014). Plant Vitrification Solution 2 (PVS2) is cryoprotectant that has composition 30\% glycerol, $15 \%$ ethylene glycol, and $15 \%$ DMSO on MS media with 0.4 M sucrose (Sakai et al. 1991). Some plants are sensitive to cryoprotectants. Therefore, to increase toleration to cryoprotectant, the plant material needed to be immersed in loading solution for 10-20 minutes before immersed in PVS2 (Kaczmarczyk et al. 2012). The composition of loading solution is $2 \mathrm{M}$ glycerol on MS media with $0.4 \mathrm{M}$ sucrose (Wang et al. 2008).

Some experiment about papaya seeds cryopreservation has reported by some researchers. Cryopreservation of papaya seeds that used Queensland genotype has been carried out by Azimi et al. (2005). Seeds with $10 \%$ moisture content being stored in liquid nitrogen had $48 \%$ germination percentage compared to the control. Papaya seeds from the cryopreservation seeds experienced $25 \%$ growth decline after planted on the field. Hervani et al. (2016) also have stored papaya seeds cv. Sukma using vitrification method. The results showed that papaya seeds which gave the best germination percentage, maximum growth potential and germination rate were seeds with 11 $13 \%$ moisture content, removed sarcotesta and mesotesta, and immersed in PVS2 for $30 \mathrm{~min}$. Germination percentage, maximum growth potential, and germination rate after cryopreservation were $38.4 \%, 38.4 \%$ and $2.2 \% /$ etmal, respectively. These results indicated that it is necessary to modify the cryopreservation method, so the stored papaya seeds have still high viability and able to grow well in the field. This experiment was preliminary experiment for seed cryopreservation of three papaya cultivars. The purpose was to obtain information about the necessity of loading treatment and the best immersion time in PVS2 for cryopreservation of papaya seeds cv. Sukma, Callina, and Caliso, so they still had considerable viability.

\section{MATERIALS AND METHODS}

\section{Study area and materials}

The experiment was done at the Center for Tropical Horticulture Studies (PKHT) Laboratory, Pasir Kuda experimental station, and Tajur experimental station of IPB University, Bogor, Indonesia.

The seeds used for this experiment were papaya seeds cv. Sukma, Callina, and Caliso. Those seeds extracted from fruit which were physiologically ripe with features of yellow color on the fruit skin as much as $25-49 \%$ (Suketi et al. 2010). Papaya fruit cv. Sukma and Caliso were taken from IPB Pasir Kuda experimental station, Bogor, while papaya fruit cv. Callina was taken from the Tajur experimental station, Bogor.

\section{Procedures}

\section{Seeds extraction}

Seeds that in the middle of the fruit were used in the experiment. The seeds were extracted by removing sarcotesta layer. Extraction began with immersing the papaya seeds with water for 48-72 h so the sarcotesta was easier to remove (Apriani 2017). After the sarcotesta was removed, the seeds were air-dried for $16 \mathrm{~h}$ to decrease the moisture content until 11-13\% (Nurlovi 2004). After that, the mesotesta was removed in order to the seeds were stored better during cryopreservation (Hervani et al 2016). Hong et al (1996) stated also that the opened seed with exposed embryo had higher survival if stored in the liquid nitrogen.

\section{Papaya seed cryopreservation procedure}

Papaya seeds moisture content has been decreased and its mesotesta has been removed. Then the seeds were immersed in the loading solutions for $20 \mathrm{~min}$. The composition of loading solution was $2 \mathrm{M}$ glycerol which was dissolved in liquid MS medium with $0.4 \mathrm{M}$ sucrose. Immersion time in the loading solution was 20 minutes (Kaczmarczyk et al. 2012). Seed without loading treatment was immersed in the sterile water for $20 \mathrm{~min}$ so the seeds had a similar condition with the other seeds with loading treatment. After that, the seeds were filtered and immersed in the plant vitrification solution-2 (PVS2) according to the immersion time in the treatment. PVS2 is cryoprotectant that had composition $30 \%$ glycerol, $15 \%$ ethylene glycol, and $15 \%$ DMSO on MS media with $0.4 \mathrm{M}$ sucrose (Sakai et al. 1991). Seeds immersion in the cryoprotectant was carried out at a room with $25{ }^{\circ} \mathrm{C}$ temperature. Then, the seeds were put into $2 \mathrm{ml}$ microtube and stored in liquid nitrogen for $24 \mathrm{~h}$. The seeds were thawed at $40^{\circ} \mathrm{C}$ for 90 $120 \mathrm{sec}$ (Wang et al. 2005). After that, the seed was immersed in the liquid MS media for $30 \mathrm{~min}$. Then, the seeds were germinated to observe the seed viability after cryopreservation. The seeds were sowed in plastic container with $1.9 \mathrm{~L}$ volume. The germination media was three stencil papers that have been moistened with sterile water. The seed viability test was done at room with 27-30 ${ }^{0} \mathrm{C}$ temperature and $37-49 \% \mathrm{RH}$.

\section{Observation variables}

Observations were made based on the seed testing protocol on ISTA (2015), i.e. moisture content (MC), germination percentage (GP), germination rate (GR), vigor index (VI), and maximum growth potential (MGP). The duration of the viability test for papaya was 21 days (Nurlovi 2004). The test duration required to break dormancy before or during the test is not taken as part of the germination test period (ISTA 2015).

Measurement of moisture content was carried out before seeds cryopreservation. The method of measuring moisture content was carried out by oven with $103{ }^{\circ} \mathrm{C}$ for 16 hours (ISTA 2015). Moisture content can be calculated using the formula:

$$
\mathrm{MC}=\frac{M 2-M a}{M 2-M 1} \times 100 \%
$$


Where $\mathrm{M}_{1}=$ petri dish weight, $\mathrm{M}_{2}=$ petri dish, and seed before drying weight, and $\mathrm{M}_{3}=$ petri dish and seed after drying weight.

Germination percentage (GP) was the observed variable used to determine seed viability physiologically. GP was determined by counting the seeds that have germinated normally at the first count and final count. The time of the first count is approximate but must be sufficient to permit the seedlings to reach a stage of development which allows for accurate evaluation (ISTA 2015). The first count (KN I) germination observation was carried out at 14 days after sowing and the final count (KN II) at 21 days after sowing (Nurlovi 2004). The criteria for normal germination was the hypocotyl grows straight and healthy, cotyledons have been completely opened, accompanied by healthy shoots (ISTA 2015). Germination percentage can be calculated using the formula:

$$
\mathrm{GP}=\frac{\sum K N I+\sum K N I I}{\text { Number of planted geed }} \times 100 \%
$$

Germination rate (GR) was observed by calculating the number of normal seedlings that appear every day from the first day to the last seedling observation, which was 21 days after sowing. Germination rate (\%/etmal) was calculated by the formula:

$$
\mathrm{GR}=\sum_{i=1}^{21} d
$$

Where $\mathrm{d}$ was percentage addition of normal seedlings per etmal $(1$ etmal $=24 \mathrm{~h})$.

The vigor index (VI) was observed by calculating the number of normal seedlings in the first count germination observation (14 days after sowing). The vigor index (\%) was calculated by the formula:

$$
V I=\frac{\sum K N I}{\text { Total planted seed }} \times 100 \%
$$

Maximum growth potential (MGP) of seeds was obtained by calculating the number of seeds that germinate with germination criteria which were reviewed from physiological aspects. The seed germinated even though the new embryo only rise the radicle. MGP was calculated on the final count of germination observation (21 days after sowing) by the formula:

$$
\text { MGP }=\frac{\text { number of germinated seed }}{\text { total planted seed }} \times 100 \%
$$

\section{Data analysis}

The experimental design used in the experiment was factorial in completely randomized design with 3 papaya cultivars, i.e. Sukma, Callina, and Caliso. Each cultivar was tested separately. The first factor was loading treatment with two levels (with loading treatment and without loading treatment). The second factor was immersion time in PVS2 with three levels $(15,30$, and $45 \mathrm{~min})$. The number of treatments in the experiment was six treatments with three replicates so total experimental unit was 18 unit.
The seeds used in each experimental unit were 50 seeds. The data were analyzed with F-test and Duncan's Multiple Range Test (DMRT) using Statistical Analysis Software (SAS) version 9.1 with $\alpha 5 \%$.

\section{RESULTS AND DISCUSSION}

\section{Cryopreservation of papaya seeds cv. Sukma}

Loading treatment and immersion time in PVS2 gave significant effect on germination percentage, germination rate, vigor index, and maximum growth potential, while their interaction only gave significant effect on vigor index (Table 1). Interaction of loading treatment and immersion time in PVS2 showed that vigor index was decreased while the immersion time in PVS2 was increased for seed without loading treatment. Whereas for seed with loading treatment, the vigor index was similar for all immersion time in PVS2. The best vigor index was $25.33 \%$ obtained at seeds without loading treatment and $15 \mathrm{~min}$ immersion in PVS2 (Table 2).

Germination percentage, germination rate, and maximum growth potential were significant at single factor (Figure 3). At loading treatment factor, seeds without loading treatment had the highest germination percentage $(37.11 \%)$, germination rate $(2.37 \% /$ etmal $)$, and maximum growth potential $(49.53 \%)$. At immersion time in PVS2 factor, seed with the highest germination percentage $(30.33 \%)$, and maximum growth potential $(41.33 \%)$ was seeds that 15 min immersed in PVS2 but did not significant with $30 \mathrm{~min}$ immersion. The highest germination rate was $2.17 \%$ /etmal, obtained by $15 \mathrm{~min}$ immersed in PVS2 (Table 2). Those results were better than Hervani et al. (2016) experiment results. Hervani et al. (2016) stated that papaya seeds cv. Sukma with11-13\% moisture content, removed sarcotesta and mesotesta, $30 \mathrm{~min}$ immersed in PVS2 before cryopreservation, had germination percentage, germination rate, and maximum growth potential $38.39 \%, 2.24 \% /$ etmal, and $38.39 \%$, respectively. Immersed in PVS2 for 15 min gave more maximum growth potential than immersed in PVS2 for $30 \mathrm{~min}$. So, the best immersion time in PVS2 for papaya seeds cV. Sukma was $15 \mathrm{~min}$. The optimal immersion time in PVS2 (15 min for papaya seeds cv. Sukma) could increase the solute concentration in the cell and protect the cell from crystal ice formation (Kaczmarczyk et al. 2012).

Table 1. The F-test results of germination percentage (GP), germination rate (GR), vigor index (VI), and maximum growth potential (MGP) on the treatment of loading (LS), immersion time in PVS2 and their interaction for papaya seeds cv. Sukma

\begin{tabular}{lcccc}
\hline \multirow{2}{*}{ Source of variation } & \multicolumn{4}{c}{ P-value } \\
\cline { 2 - 5 } & GP & GR & VI & MGP \\
\hline LS & $0.00^{*}$ & $0.00^{*}$ & $0.00^{*}$ & $0.00^{*}$ \\
PVS2 & $0.01^{*}$ & $0.00^{*}$ & $0.03^{*}$ & $0.00^{*}$ \\
LS*PVS2 & $0.19^{\text {ns }}$ & $0.40^{\text {ns }}$ & $0.01^{*}$ & $0.09^{\text {ns }}$ \\
\hline
\end{tabular}

Note: LS = loading treatment, PVS2 = plant vitrification solution2 , $*=$ treatment gave significant effect on observed variables $(\alpha=5 \%),{ }^{\text {ns }}=$ treatment gave non-significant effect on observed variables $(\alpha=5 \%)$. 
Compared to initial viability, the seeds viability after cryopreservation was decreased. Seeds had initial germination percentage, germination rate, vigor index, and maximum growth potential were $81.11 \%, 2.48 \%$ /etmal, $37.78 \%$, and $85.56 \%$, respectively (Table 2 ). The viability was decreased because every living cell that store in the liquid nitrogen would be damage and the result from this research showed that loading and immersion in PVS2 treatment could reduce it.

Data analysis stated that papaya seeds cv. Sukma had decreased germination percentage, germination rate, vigor index, and maximum growth potential while the immersion time in PVS2 increased (Table 2 and Figure 1). These showed that immersion in PVS2, initially, protected cell from damage during cryopreservation, but also caused the cell damage. Immersion in PVS2 for 15 min could protect the cell during cryopreservation because of vitrification (Gonzalez-Arnao et al. 2007). Vitrification is the freezeavoidance mechanism that enables hydrated cells, tissues, and organs to withstand exposure to the temperature of liquid nitrogen. Vitrification defined as the transition of the liquid phase to an amorphous glassy solid at the glass transition temperature. The glass may contribute to preventing tissue collapse, solute concentration, and $\mathrm{pH}$ alterations during dehydration. Vitrification is achieved by direct immersion in liquid nitrogen of samples which have been dehydrated at a non-freezing temperature. The vitrified state is achieved in systems that become sufficiently concentrated after a drastic desiccation process and that are cooled sufficiently rapidly so that the increase in cellular viscosity inhibits molecular rearrangement of water into a crystalline pattern. As cooling progresses, the viscosity of intracellular solutes increases to the point where translational molecular motion is essentially halted and the solution becomes a glass. The resultant solid retains the random molecular arrangement of a liquid, but has the mechanical properties of a solid.

PVS2 could protect cell from damage because PVS2 dehydrated intracellular water and changed it with PVS2 solution. The intracellular solute would be solid and prevent crystal ice formation when stored in the liquid nitrogen. Hervani et al. (2016) stated that papaya seeds cv. Sukma cells that immerse in cryoprotectant had cell wall more tightly and the intracellular water was exchanged by the cryoprotectant (thick solution). The seeds cell wall after cryopreservation were more stretch and some were damaged. Vendrame et al. (2014) stated the similar report that cryoprotectant exchange the intracellular water of orchid seeds (orthodox seeds), so the membrane content is more solid and make amorphous or vitreous forming when storage in the liquid nitrogen. There was some membrane content that did not make amorphous form so the ice crystal forming and cell damage.

Immersion more than $15 \mathrm{~min}$ (overexposure) to PSV2 may cause damage to the cells owing to the toxic nature of the PVS2 or excessive dehydration (Kaczmarczyk et al. 2012). Vendrame et al. (2014) stated that cryoprotectant (PVS2) was toxic that caused osmotic stress, cell death, and cell morphogenetic. Some of papaya seeds cv. Sukma was death, and was expected caused by excessive dehydration so it could not germinate.

Table 2. Interaction of loading (LS) treatment and immersion time in PVS2 on vigor index (VI, \%) of papaya seeds cv. Sukma after cryopreservation

\begin{tabular}{lccc}
\hline \multirow{2}{*}{\multicolumn{1}{c}{ Treatment }} & \multicolumn{3}{c}{ Immersion time in } \\
& PVS2 (min) \\
\cline { 2 - 4 } & $\mathbf{1 5}$ & $\mathbf{3 0}$ & $\mathbf{4 5}$ \\
\hline Without loading treatment & $25.33 \mathrm{a}$ & $16.00 \mathrm{~b}$ & $6.67 \mathrm{c}$ \\
With loading treatment & $5.33 \mathrm{c}$ & $2.67 \mathrm{c}$ & $1.33 \mathrm{c}$ \\
\hline
\end{tabular}

Note: The similar letter in the table indicates that the treatment gives a nonsignificant effect at DMRT test $(\alpha=5 \%)$. Papaya seeds cv. Sukma without loading and immersion in PVS2 treatment had germination percentage, germination rate, vigor index, and maximum growth potential $0 \%$. The initial germination percentage, initial germination rate, initial vigor index, and initial growth maximum potential papaya seeds cv. Sukma were $81.11 \%, 2.48 \% /$ etmal, $37.78 \%$, and $85.56 \%$, respectively.
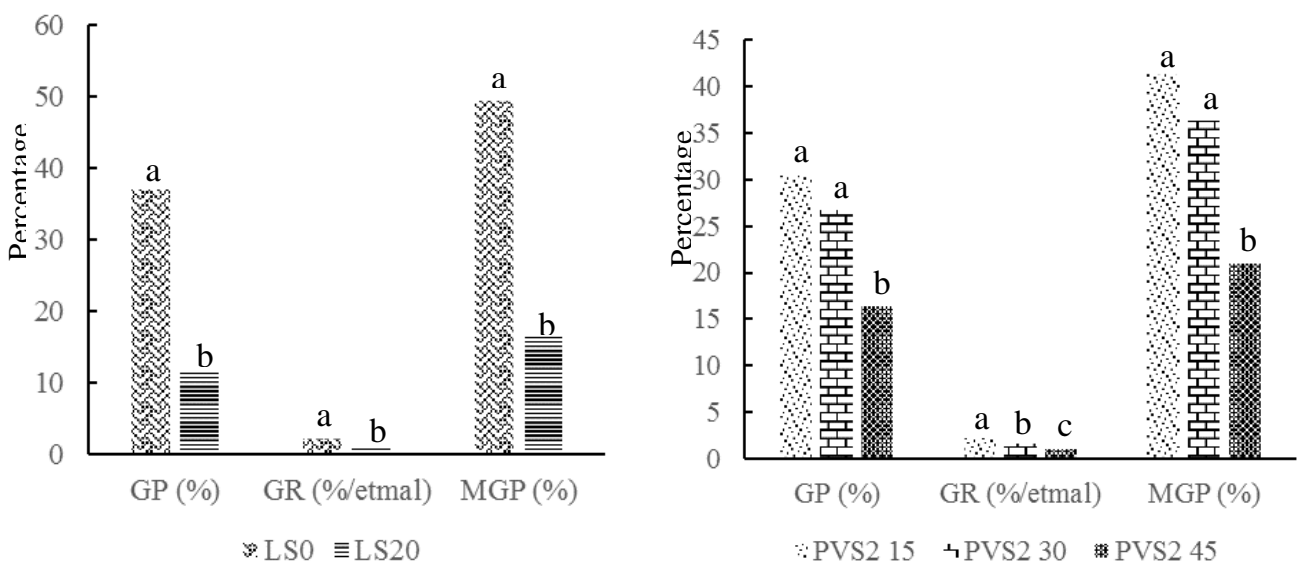

Figure 1. Effect of loading treatment (left) and immersion time in PVS2 (right) on germination percentage (GP), germination rate (GR), and maximum growth potential (MGP) papaya seed cv. Sukma after cryopreservation 
Table 3. The F-test results of germination percentage (GP), germination rate (GR), vigor index (VI), and maximum growth potential (MGP) on the treatment of loading (LS), immersion time in PVS2 and their interaction for papaya seeds cv. Callina

\begin{tabular}{lcccc}
\hline \multirow{2}{*}{ Source of variation } & \multicolumn{4}{c}{ P-value } \\
\cline { 2 - 5 } & GP & GR & VI & MGP \\
\hline LS & $0.24^{\mathrm{ns}}$ & $0.20^{\mathrm{ns}}$ & $0.40^{\mathrm{ns}}$ & $0.32^{\mathrm{ns}}$ \\
PVS2 & $0.13^{\mathrm{ns}}$ & $0.13^{\mathrm{ns}}$ & $0.09^{\mathrm{ns}}$ & $0.16^{\mathrm{ns}}$ \\
LS*PVS2 & $0.14^{\mathrm{ns}}$ & $0.12^{\text {ns }}$ & $0.09^{\mathrm{ns}}$ & $0.11^{\mathrm{ns}}$ \\
\hline N
\end{tabular}

Note: LS = loading treatment, PVS2 = plant vitrification solution$2, *=$ treatment gave significant effect on observed variables $(\alpha=5 \%),{ }^{n s}=$ treatment gave non-significant effect on observed variables $(\alpha=5 \%)$

Table 4. Germination percentage (GP), germination rate (GR), vigor index (VI), and maximum growth Potential (MGP) of papaya seeds cv. Callina after cryopreservation

\begin{tabular}{lcccc}
\hline \multirow{1}{*}{ Treatment } & \multicolumn{5}{c}{ Observed variables } \\
\cline { 2 - 5 } & $\begin{array}{c}\text { GP } \\
(\boldsymbol{\%})\end{array}$ & $\begin{array}{c}\text { GR } \\
(\boldsymbol{\%} / \mathbf{e t m a l})\end{array}$ & $\begin{array}{c}\text { VI } \\
(\boldsymbol{\%})\end{array}$ & $\begin{array}{c}\text { MGP } \\
(\boldsymbol{\%})\end{array}$ \\
\hline $\begin{array}{l}\text { Initial seeds viability } \\
\text { Loading treatment }\end{array}$ & 84.67 & 6.13 & 51.33 & 86.67 \\
$\quad$ Without loading treatment & $1.78 \mathrm{a}$ & $0.15 \mathrm{a}$ & $1.33 \mathrm{a}$ & $3.11 \mathrm{a}$ \\
$\quad \begin{array}{l}\text { With loading treatment } \\
\text { Immersion time in PVS2 }\end{array}$ & $2.89 \mathrm{a}$ & $0.26 \mathrm{a}$ & $2.00 \mathrm{a}$ & $4.89 \mathrm{a}$ \\
$\quad$ 15 min & $3.67 \mathrm{a}$ & $0.33 \mathrm{a}$ & $3.00 \mathrm{a}$ & $6.33 \mathrm{a}$ \\
$\quad 30$ min & $2.00 \mathrm{a}$ & $0.17 \mathrm{a}$ & $1.00 \mathrm{a}$ & $3.67 \mathrm{a}$ \\
$\quad$ 45 min & $1.33 \mathrm{a}$ & $0.13 \mathrm{a}$ & $1.00 \mathrm{a}$ & $2.00 \mathrm{a}$ \\
Without loading and & & & & \\
immersion in PVS2 treatment & 0.00 & 0.00 & 0.00 & 0.00 \\
\hline
\end{tabular}

Note: The similar letter in a similar column indicates that the treatment gives a nonsignificant effect at DMRT test ( $\alpha$ 5\%).

Papaya seeds cv. Sukma was orthodox seeds because still could germinate while stored in $-20{ }^{\circ} \mathrm{C}$ for three months but did not germinate after one year (Wulandari 2007, Oktaviani 2012). So, seed cryopreservation with the optimal treatment could be expected to prolong the storage period of papaya seeds cv. Sukma. The optimum treatment for papaya seeds cv. Sukma was desiccation until 11-13\%, removed sarcotesta and mesotesta, immersed in PVS2 for $15 \mathrm{~min}$, direct immerse in liquid nitrogen, thawing at $40{ }^{\circ} \mathrm{C}$ for $90-120 \mathrm{sec}$, immersed in liquid MS media for $30 \mathrm{~min}$, and viability test. The other orthodox seeds could be cryopreserved with the other treatment. Chmielarz (2010) reported that desiccated seed of Alnus glutinosa L. (orthodox seeds) with 8-13\% moisture control after stored in liquid nitrogen had similar viability with desiccated seed that store in $-3{ }^{\circ} \mathrm{C}$. Galdiano et al. (2012) also reported that Dendrobium seeds that dehydrated with PVS2 and $1 \%$ phloroglucinol for 60 minutes at $0{ }^{\circ} \mathrm{C}$ could store in the liquid nitrogen. These seeds had $79 \%$ germination percentage and could grow normally.

\section{Cryopreservation of papaya seeds cv. Callina}

At papaya seeds cv. Callina, loading treatment, immersion time in PVS2, and their interaction did not give significant effect on germination percentage, germination rate, vigor index, and maximum growth potential after cryopreservation (Table 3). Data analysis showed that the viability of papaya seeds cv. Callina were low after cryopreservation even though the initial seeds viability was high (Table 4). These were caused by crystal ice formation in the seed cells while freezing and thawing (warming) procedures. Crystallization during freezing is a complex process that comprises a number of critical steps: nucleation, growth of crystals and/or recrystallization, which are considered the main elements affecting survival of cells subjected to cryopreservation (Gonzalez-Arnao et al. 2007).

Gonzalez-Arnao et al. (2007) stated that the formation of ice crystals detrimental to cellular integrity can also take place during warming procedure. A potential cause of injury is the use of a low warming rate to attain room temperature. Under slow warming conditions, there is a tendency for large crystals to grow at the expense of small ones, or for devitrification (ice crystal formation) to take place, when unstable glasses have been formed during cooling. Unstable glasses are obtained during rapid immersion in liquid nitrogen of little concentrated samples; such glasses are considered metastable, because devitrification can occur upon rewarming, returning to either a liquid or crystalline state (Gonzalez-Arnao et al. 2007). So, devitrification could be prevented by fast thawing/warming at $40{ }^{\circ} \mathrm{C}$ for $1-2 \mathrm{~min}$.

According to Oktaviani (2012), papaya seeds cv. Callina were orthodox seed but for cryopreservation need different treatment from Sukma. Callina had low viability after cryopreservation with similar treatment with Sukma. So, to increase the viability, it should try another treatment. Chmielarz (2009) stated that the key problem in the cryopreservation of orthodox seeds was the identification of their optimum (safe) moisture content. Chmielarz (2009) suggested that the safe range of moisture content of orthodox seeds preserved in liquid nitrogen was $3.8-11 \%$. It was consistent with Azimi et al. (2005) that decreased the seed moisture content until $10 \%$ and stored directly in the liquid nitrogen for papaya seeds cv. Queensland (orthodox seeds). The result showed that the seeds could germinate with $48 \%$ germination percentage. The similar treatment also used for papaya seeds cv. Formosa and Mamaohinzo by Obisesan et al. (2005). Obisesan et al. (2005) decreased the seed moisture content until 6.5-7\% and stored directly in the liquid nitrogen. The seeds could germinate with 50-56\% germination percentage. According to all literature, papaya seeds var. Callina could be cryopreserved only with desiccation. The moisture content could decrease until $6.5-10 \%$ before store directly in the liquid nitrogen.

\section{Cryopreservation of papaya seeds cv. Caliso}

Loading treatment and immersion time in PVS2 gave significant effect on germination percentage, germination rate, vigor index, and maximum growth potential, while the interaction gave significant effect on germination percentage, germination rate, and maximum growth potential (Table 5). At seed without loading treatment, 
germination percentage, germination rate, and growth maximum potential were similar on the all immersion time in PVS2. At the seed with loading treatment, the highest germination percentage $(60.00 \%)$, germination rate $(4.35 \%)$, and maximum growth potential $(64.17 \%)$ were on 30 min immersed in PVS2, and decreased on more or less than 30 min (Table 6). Vigor index only significant on single factor. The best vigor index was obtained on seed with loading treatment. Immersion time that gave the best vigor index was $30 \mathrm{~min}$ but did not significant with $15 \mathrm{~min}$ (Figure 2)

Seed without loading and immersion in PVS2 treatment did not germinate after cryopreservation, because the seed cells did not protect by cryoprotectant. Compared to the initial viability, the viability after cryopreservation was decreased. The initial germination percentage, germination rate, vigor index, and growth maximum potential were $92.18 \%, 5.04 \%$ etmal, $25.67 \%$, dan $96.80 \%$, respectively (Table 6).

So, the papaya seeds cv. Caliso could be cryopreserved with some treatment, i.e. desiccation until 11-13\%, removed sarcotesta and mesotesta, loading treatment in the loading solution (liquid $\mathrm{MS}+2 \mathrm{M}$ glycerol $+0.4 \mathrm{M}$ sucrose) for $20 \mathrm{~min}$, immersed in PVS2 for $30 \mathrm{~min}$, direct immerse in liquid nitrogen, thawing at $40{ }^{\circ} \mathrm{C}$ for $90-120$ $\mathrm{sec}$, immersed in liquid MS media for $30 \mathrm{~min}$, and viability test. These result consistent with Ashmore et al. (2009) that papaya seeds cv. Solo and Queensland could be cryopreserved with decreased moisture content to $5 \%$ and gave pre-culture in medium with $2 \mathrm{mM} \mathrm{GA}_{\mathrm{s}}$ for $15 \mathrm{~min}$. This treatment made papaya seeds cv. Solo and Queensland could germinate more than $80 \%$. It showed that some papaya seeds from another cultivar need to treat more before cryopreservation (need different treatment from Sukma and Callina).

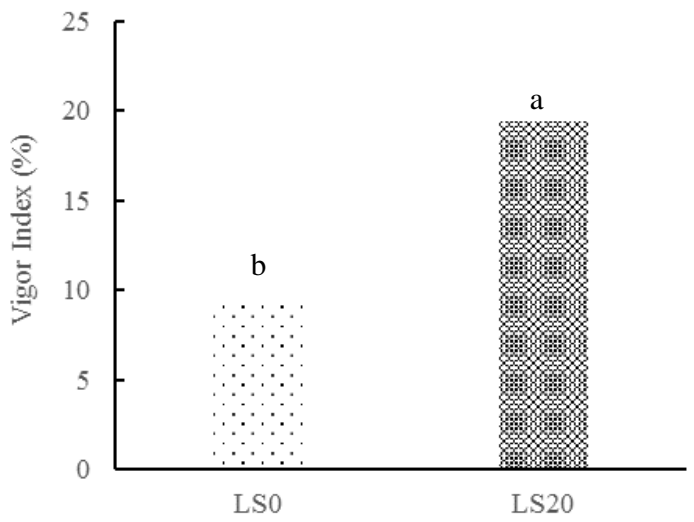

Table 5. The F-test results of germination percentage (GP), germination rate (GR), vigor index (VI), and maximum growth potential (MGP) on the treatment of loading (LS), immersion time in PVS2 and their interaction for papaya seeds cv. Callina

\begin{tabular}{lcccc}
\hline \multirow{2}{*}{ Source of variation } & \multicolumn{4}{c}{ P-value } \\
\cline { 2 - 5 } & GP & GR & VI & MGP \\
\hline LS & $0.00^{*}$ & $0.00^{*}$ & $0.02^{*}$ & $0.00^{*}$ \\
PVS2 & $0.00^{*}$ & $0.00^{*}$ & $0.03^{*}$ & $0.01^{*}$ \\
LS*PVS2 & $0.04^{*}$ & $0.03^{*}$ & $0.07^{\text {ns }}$ & $0.04^{*}$ \\
\hline
\end{tabular}

Note: $\mathrm{LS}=$ loading treatment, PVS2 = plant vitrification solution$2, *=$ treatment gave significant effect on observed variables $(\alpha=5 \%),{ }^{n s}=$ treatment gave non-significant effect on observed variables $(\alpha=5 \%)$

Table 6. Interaction of loading (LS) treatment and immersion time in PVS2 on germination percentage (GP), germination rate (GR), and maximum growth potential (MGP) of Caliso papaya seeds after cryopreservation

\begin{tabular}{cccc}
\hline & \multicolumn{3}{c}{ Immersion time in PVS2 } \\
\cline { 2 - 4 } Treatment & $\mathbf{1 5}$ & $\mathbf{3 0}$ & $\mathbf{4 5}$ \\
\hline Germination percentage (\%) & & & \\
$\quad$ Without loading treatment & $12.50 \mathrm{c}$ & $30.00 \mathrm{bc}$ & $27.50 \mathrm{bc}$ \\
$\quad$ With loading treatment & $40.00 \mathrm{~b}$ & $60.00 \mathrm{a}$ & $30.00 \mathrm{bc}$ \\
Germination rate (\%/etmal) & & & \\
$\quad$ Without loading treatment & $0.67 \mathrm{c}$ & $2.23 \mathrm{~b}$ & $1.73 \mathrm{bc}$ \\
$\quad$ With loading treatment & $2.77 \mathrm{~b}$ & $4.35 \mathrm{a}$ & $1.93 \mathrm{~b}$ \\
Maximum growth potential (\%) & & & \\
$\quad$ Without loading treatment & $16.67 \mathrm{~b}$ & $34.17 \mathrm{~b}$ & $33.33 \mathrm{~b}$ \\
$\quad$ With loading treatment & $46.67 \mathrm{~b}$ & $64.17 \mathrm{a}$ & $37.50 \mathrm{~b}$ \\
\hline
\end{tabular}

Note: The similar letter in a similar variable indicates that the treatment gives a nonsignificant effect at DMRT test $(\alpha=5 \%)$. Papaya seeds cv. Caliso without loading and immersion in PVS2 treatment had germination percentage, germination rate, vigor index, and maximum growth potential $0 \%$. The initial germination percentage, initial germination rate, initial vigor index, and initial growth maximum potential papaya seeds cv. Sukma were $92.18 \%, 5.04 \% /$ etmal, $25.67 \%$, dan $96.80 \%$, respectively.

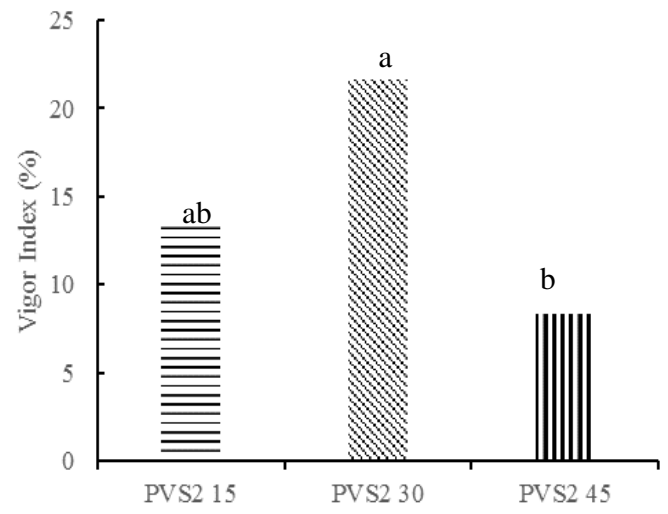

Figure 2. Effect of loading treatment (left) and immersion time in PVS2 (right) on vigor index of Caliso papaya seed after cryopreservation 
Papaya seeds var. Caliso needs loading treatment in order to the cells could adapt well while stored in the liquid nitrogen. Loading solution could increase the dehydration tolerance on sensitive cryoprotectant plants (intolerance to dehydration and osmosis stress) (Vendrame et al. 2014). Loading treatment increased the membrane cell permeability in order to cryoprotectant could enter the membrane cell (Vendrame et al. 2014). The increasing permeability also made dehydration happened more slowly so prevent irreversible plasmolysis (Roostika et al 2007). The permeability of membrane cell increased with the increasing of osmosis concentration in the cell. Furthermore, compared to Sukma, Caliso needs more immersion time in PVS2, i.e., $30 \mathrm{~min}$, because loading treatment made the permeability of membrane increased, so the vitrification required more time (dehydration more slowly).

The seed characteristic of papaya seeds cv. Caliso did not know yet. But, according to t-test $(\alpha=5 \%)$ that compared the viability after cryopreservation between Caliso, Sukma, and Callina, papaya seeds cv. Caliso had a similar characteristic with papaya seeds cv. Sukma ( $>5 \%)$. Nevertheless, papaya seeds cv. Caliso needed different treatment to get good viability after cryopreservation. Papaya seeds cv. Sukma did not need loading treatment but Caliso needed it, and the immersion time in PVS2 was 15 min for Sukma and $30 \mathrm{~min}$ for Caliso.

According to Elliot et al. (2017), plant material could survive after cryopreservation because of the optimal cellular dehydration and the intracellular ice formation (IIF) level. The optimal cellular dehydration (in the presence of cryoprotectant/PVS2), which could be achieved by allowing regulated extracellular ice crystal growth during controlled cooling. The bound water compartment is associated with structural organization of membranes and organelles, and polymeric components such as proteins. As dehydrative freezing progresses to impinge on restricted water, cell structures can become unstable leading to irreversible injury under some slow cooling conditions. The second factor observed at higher cooling rates was related to intracellular ice formation (IIF), with the incidence of injury due to IIF increasing with increasing cooling rate. The balance between these two factors results in a maximal survival for a particular cell type across a limited cooling rate profile.

From the experiment, we concluded that papaya seeds cv. Sukma, Callina, and Caliso had different responses when stored by cryopreservation. For papaya seeds cv. Sukma, seeds without loading treatment and $15 \mathrm{~min}$ immersion in PVS2 were the best treatment that obtained the best viability. For papaya seeds cv. Callina, we should to try another treatment to get high viability after cryopreservation. For papaya seeds cv. Caliso, seeds with loading treatment and $30 \mathrm{~min}$ immersion in PVS2 were the best treatment that obtained the best viability.

\section{ACKNOWLEDGEMENTS}

The authors thanks to the Indonesia Endowment Fund for Education (LPDP), Indonesian Ministry of Finance (Kemenkeu RI) that has funded this project and the authors also thanks to the Center for Tropical Horticulture Studies (PKHT-IPB), Bogor, Indonesia for giving permission to author to use materials and experimental equipment in the experimental station and laboratory.

\section{REFERENCES}

Apriani KR. 2017. Pengaruh umur panen terhadap kualitas kematangan pascapanen buah dan viabilitas benih pepaya sukma [Tesis]. Institut Pertanian Bogor, Bogor. [Indonesian]

Ashmore SE, Drew RA, O'Brien, Parisi A. 2009. Cryopreservation of papaya (Carica papaya L.) seed: overcoming dormancy and optimizing seed desiccation and storage conditions. Acta Hortic. 839: 229-236.

Azimi M, Brien C, Ashmore S, Drew R. 2005. Cryopreservation of Papaya Germplasm. Acta Hortic. 692, ISHS 2005: 43-50.

Chmielarz P. 2009. Cryopreservation of dormant orthodox seeds of forest trees: mazzard cherry (Prunus avium L.). Ann For Sci. 66:405-415

Chmielarz P. 2010. Cryopreservation of orthodox seeds of Alnus glutinosa. Cryo Lett. 31 (2): 139-146.

Efendi D, Litz RE. 2003. Cryopreservation of Avocado. Proceedings V World Avocado Congress (Actas V Congreso Mundial del Aguacate) 2003. 111-114.

Elliot GD, Wang S, Fuller BJ. 2017. Cryoprotectants: A review of the actions and applications of cryoprotective solutes that modulate cell recovery from ultra-low temperatures. Cryobiol. 76: 74-91.

Galdiano JRF, Lemos EGM, Faria RT, Vendrame WA. 2012. Cryopreservation of Dendrobium hybrid seeds and protocorms as affected by phloroglucinol and Supercool X1000. Sci Hortic. 148: 154-160.

Gonzalez-Arnao MT, Panta A, Roca WM, Escobar RH, Engelmann F. 2007. Development and large-scale application of cryopreservation techniques for shoot and somatic embryo cultures of tropical crops. Plant Cell Tiss Org Cult. DOI: 10.1007/s11240-007-9303-7.

Hervani D, Efendi D, Suhartanto MR, Purwoko BS. 2016. Cryopreservation for long-term plant germplasm storage. In: Efendi D, Maharijaya A (eds). Proceeding International Seminar on Tropical Horticulture 2016. Pusat Kajian Hortikultura Tropika-LPPM IPB, Bogor, 28-29 November 2016. [Indonesian]

Hong TD, S. Linington, R.H. Ellis. 1996. Seed Storage Behaviour: a Compendium. Handbooks for GenBank: No. 4. International Plant Genetic Resources Institute, Rome.

ISTA. 2015. International Rules for Seed Testing. International Seed Testing Association, Bassersdorf, Switzerland.

Kaczmarczyk A, Bryn F, Menon A, Phang PY, Al-Hanbali A, Bunn E, Mancera LR. 2012. Current issues in plant cryopreservation. In: Katkov I (ed). Current Frontiers in Cryobiology. In Tech, Rijeka, Croatia.

Nurlovi D. 2004. Viabilitas benih pepaya (Carica papaya L.) pada beberapa tingkat kadar air awal selama penyimpanan [Skripsi]. Institut Pertanian Bogor, Bogor. [Indonesian].

Obisesan IO, Veiga RFA, Barbosa W, Meletti LMM, Lago AA, Medina PF, Razera IF. 2005. Seed Cryoconservation of Passion Fruit, Papaya and Guava Germplasm. Anais do Simpósio de Recursos Genéticos Latino Americano e do Caribe. III SIRGEALC.

Oktaviani L. 2012. Pengujian sifat benih pepaya (Carica papaya L.) dengan perlakuan penyimpanan temperatur rendah [Skripsi]. Institut Pertanian Bogor, Bogor. [Indonesian].

PKHT. 2018. Varietas Buah. Pusat Kajian Hortikultura Tropika, Bogor. http://pkht.ipb.ac.id/index.php/category/inovasi/varietas-buah/ [Indonesian] 
Rahmah S, Mubbarakh SA, Ping KS, Subramaniam S. 2015. Effect of droplet-vitrification cryopreservation based on physiological and antioxidant enzyme activities of Brassidium Shooting Star Orchid. Sci World J 2015: 961793. DOI: 10.1155/2015/961793 :1-10.

Roostika I, Darwati I, Megia R. 2007. Kriopreservasi tanaman purwoceng (Pimpinella pruatjan Molk.) dengan teknik vitrifikasi. Berita Biologi. 8(6):423-431. [Indonesian].

Sakai A, Kobayashi S, Oiyama I. 1991. Cryopreservation of nucellar cells of navel orange (Citrus sinensis Osb.) by a simple freezing method. Plant Sci 74: 243-248.

Salomao AN, Mundim RC. 2000. Germination of papaya seed in response to desiccation, exposure to subzero temperatures, and gibberellic acid. Hortic Sci. 35(5): 904-906.

Silva JAT, Rashid Z, Nhut DT, Sivakumar D, Gera A, Souza Jr MT, Tennant PF. 2007. Papaya (Carica papaya L.) biology and biotechnology. Tree For Sci Biotechnol. 1(1): 47-73.

Silva LC, Paiva R, Swennen R, Andre E, Panis B. 2013. Shoot-tip cryopreservation by droplet vitrification of Byrsonima intermedia A.
Juss.: a woody tropical and medicinal plant species from Brazillian cerrado. Cryo Lett. 34(4): 338-348.

Suketi K, Poerwanto R, Sujiprihati S, Widodo WD. 2010. Studi karakter mutu buah pepaya IPB. J Hort Indonesia 1 (1): 17-26.

Vendrame W, Faria RT, Sorace M, Sahyun SA. 2014. Review orchid cryopreservation. Cienc Agrotec 38(3): 213-229.

Wang QC, Panis B, Engelman F, Lombardi M, Valkonen JPT. 2008. Cryotherapy of shoot tips: a technique for pathogen eradication to produce healthy planting materials and prepare healthy plant genetic resources for cryopreservation. Ann Applied Biol. 154: 351-363.

Wang YL, Fab MJ, Liaw SI. 2005. Cryopreservation of in vitro-grown shoot tips of papaya (Carica papaya L.) by vitrification. Bot Bull Acad Sin. 46: 29-34.

Wulandari RR. 2007. Pengujian sifat benih pepaya (Carica papaya L.) dengan penyimpanan suhu dingin [Tesis]. Institut Pertanian Bogor, Bogor [Indonesian]. 